\title{
Penggunaan Media BIP Video Call untuk Meningkatkan Kemampuan Speaking Mahasiswa
}

\author{
Syaifullah $^{1]}$, Refika Andriani2], M. Fadhly Farhy Abbas ${ }^{3]}$ \\ Universitas Lancang Kuning \\ E-mail: ${ }^{1]}$ syaifullah@unilak.ac.id \\ ${ }^{2]}$ andriarefi@gmail.com \\ ${ }^{3]}$ fadhly@unilak.ac.id
}

\begin{abstract}
Abstrak
Berdasarkan hasil quiz harian pada matakuliah speaking, peneliti menemukan kemampuan mereka berada di level poor. Sebagai solusi dari masalah tersebut, peneliti telah menggunakan BIP Video Call untuk meningkatkan kemampuan Speaking sertatelah menemukan faktor-faktor yang memengaruhi perubahan pada kemampuan speaking mereka. Penelitian ini telah menggunakan desain Penelitian Tindakan Kelas (PTK) sebanyak satu siklus dengan jumlah pertemuan sebanyak empat kali termasuk tes. Penelitian ini memiliki beberapa prosedur; Planning, Action, Observation, and Reflection. Penelitian ini tidak memiliki teknik sampling, tapi meamakai istilah partisipan. Mahasiswa yang telah menjadi partisipan dari penelitian ini adalah mahasiswa Semester II pada Program Studi Pendidikan Bahasa Inggris, Fakultas Keguruan dan Ilmu Pendidikan (FKIP) Universitas Lancang Kuning (UNILAK) yang diajar pada matakuliah Speaking, khususnya Speaking for Everyday Communication. Penelitian ini merupakan penelitian campuran antara kuantitatif dan kualitatif. Data kualitatif diperoleh dengan menggunakan instrumen wawancara. Sedangkan data kuantitatif diperoleh melalui intrumen tes, yaitu tes kemampuan speaking. Hasil yang telah diperoleh dari penelitian ini yaitu adanya peningkatan nilai rata-rata speaking mereka dari angka 52 menjadi 53.2. masih kategori poor. Ada dua faktor yang memengaruhi terjadinya perubahan nilai rata-rata tersebut; pertama kualitas suara yang dihasilkan oleh BIP Video Call lebih jelas dan kedua videonya menghasilkan visualisasi yang lebih jernih. Kesimpulannya, BIP Video Call dapat membantu mahasiswa dalam memperlancar proses komunikasi mereka dalam mata kuliah speaking.
\end{abstract}

Kata kunci: Media, BIP video call, speaking

\section{Abstract}

\section{Using BIP Video Call in Improving Students'Speaking Skill}

Related to speaking daily quiz score, resarcher found that their ability was still low or categorized poor. As solution, resarcher found a new media, it was BIP Video Call. It has been applied for one cycle or four meetings in speaking class. It was classroom action research which has been expected that students' speaking skill could be improved. There were four procedures in condcuting this research, such as planning, action, observation, and reflection. In this research, the researcher did not use populationa and sampling terminologies, but it was namely as participant or research partisipatory. Students second semester of English Education Department FKIP UNILAK were as participant of this research who joined in speaking class, particularly 
Speaking for Everyday Communication. It was such mix model reseacrh design. It has quantitative and qualitative data. Quantiative data was taken from speaking test. Meanwhile, qualitative data was taken from interview, whatsapp text interview. The result of this research showed that there was an improvement on students speaking average score from 52 to 53.2 was still categorized in to poor. There were two factors influence the score changing, BIP video call had clearer sound and vivid visualization. In short, BIP video class helps students communicate easier in their speaking class.

Keywords: Media, BIP video call, speaking

\section{PENDAHULUAN}

Speaking adalah salah satu matakuliah Productive Skill (PS) yang wajib diambil oleh mahasiswa pendidikan bahasa Inggris Fakultas Keguruan dan Ilmu Pendidikan (FKIP) Universitas Lancang Kuning (UNILAK) Pekanbaru. Matakuliah ini dijadwalkan pada tiga semester. Semester II, Mahasiswa wajib mengambil mata kuliah ini, yang disebut dengan Speaking for Everyday Communication. Pada semester III, mata kuliah ini bernama Speaking for Group Activities, dan pada semester IV, mata kuliah ini bernama Speaking for Formal Setting. Pada masingmasing matakuliah speaking memiliki tujuan khusus yang berbeda, namun secara umum tujuannya sama yaitu meningkatkan dan mengoptimalkan kemampuan speaking mahasiswa.

Berkaitan dengan tujuan matakuliah di atas, Speaking merupakan gambaran kesuksesan atau kegagalan mahasiswa dalam belajar bahasa. Dalam kehidupan sehari-hari, mahasiswa akan mudah diketahui kemampuan berbahasanya apa bila mereka sering menggunakan bahasanya dalam bentuk lisan atau speaking. Masyarakat tidak akan menanyakan berapa IPK mereka, tapi masyarakat langsung dapat mengetahui dari proses interaksi, baik itu dengan sesama mahasiswa ataupun dengan masyarakat yang mengetahuinya.
Selanjutnya, sudah satu tahun berjalan, Proses interaksi berbahasa lisan mahasiswa tidak dapat dilakukan sebagaimana yang diharapkan. COVID 19, dia menjadi penghalang dan pembatas antara sesama mahasiswa dan mahasiswa dengan dosen untuk melakukan proses interaksi secara langsung. Sejauh ini proses perkuliahan sudah dilakukan secara online dengan menggunakan media pendukung yang bervariasi, seperti Blended learning (BL), Zoom, atau WhatsApp (WA). Berdasarkan Media yang digunakan di atas, target yang ingin dicapai pada matakuliah Speaking belum bisa dipenuhi. Berdasarkan hasil wawancara dengan beberapa orang mahasiswa, hal ini disebabkan oleh beberapa alasan. Pertama, lemahnya jaringan yang ada pada wilayah atau daerah mahasiswa berada sehingga video tatap muka melaui Zoom atau WA tidak menghasilkan audio visual yang jelas. Kedua, jika proses interaksi Speaking antara mahasiswa dan dosen melalui zoom meeting, tidak semua mahasiswa bisa berinteraksi dengan dosen karna keterbatasan waktu yang ada. Ketiga, pada saat kuliah dengan menggunakan video call WA, hanya empat orang mahasiswa dan dosen yang bisa berinteraksi pada media tersebut sehingga mahasiswa yang lainnya juga tidak akan dapat giliran untuk beriteraksi. 
Dari uraian di atas, dapat disimpulkan bahwa proses interaksi yang telah dilakukan melalui Zoom atau video call WA belum bisa membantu kelancaran proses Speaking secara maksimal. Seiring dengan perkembangan teknologi, pada saat ini peneliti sedang mempelajari dan mendalami satu media yang dapat membantu proses interaksi mahasiswa dengan dosen yang akan digunakan pada matakuliha speaking, yaitu $B I P$ Video call. Sejauh yang peneliti pahami, BIP video call memiliki kelebihan dari pada WA video call. Salah satu diantaranya yaitu BIP video call mampu menampung 10 orang mahasiswa dan dosen untuk melakukan interaksi, speaking dalam waktu yang bersamaan. Oleh karena itu, peneliti sangat tertarik dan memiliki antusias yang tinggi untuk mengaplikasikan media BIP video call pada penelitian ini dengan judul "Penggunaan Media BIP Video Call untuk meningkatkan kemampuan speaking mahasiswa semester II Pendidikan bahasa Inggris FKIP UNILAK" dengan harapan dapat membantu dosen untuk memaksimalkan proses interaksi diantara mereka, dosen dan mahasiswa, pada matakuliah Speaking for Everyday Communication.

Dari latar belakang masalah di atas, dapat dirumuskan bahwa proses pembelajaran speaking yang sudah berlangsung satu tahun terakhir tidak sesuai dengan apa yang diharapkan. Hal ini dipengaruhi oleh dua faktor yaitu media yang kurang mendukung dan kondisi alam yang belum memungkinkan untuk melakukan tatap muka. Oleh sebab itu, salah satu solusinya, peneliti akan menggunakan media BIP Video call pada semester yang akan datang, dengan harapan mampu mengoptimalkan proses interaksi antara mahasiswa dan dosen pada matakuliah tersebut.

Al- Jarf (2012) mendefenisikan speaking adalah sebuah kemampuan oral untuk mencapai tujuan pragmatis melalui wacana interaktif dengan pembicara lain dari bahasa yang sama. Speaking sebagai salah satu bentuk komunikasi untuk berinteraksi dengan orang-orang secara lisan. Dalam speaking orang-orang diharapkan untuk dapat mengkomunikasikan ideide, perasaan, dan pendapat mereka. Tujuannya adalah agar peserta dapat menciptakan interaksi sosial yang nyaman dan berkomunikasi dengan baik. Sejalan dengan pernyataan tersebut, Hakim (2015) menyatakan pada umumnya para siswa di Indonesia enggan berbicara bahasa Inggris karena memiliki permasalahan kurangnya perbendaharaan kata dalam Bahasa Inggris (vocabularies) dan frase-frase (phrases) untuk mengekspresikan ide-ide mereka dalam bahasa Inggris.

Ada beberapa penelitian terdahulu yang telah dilakukan oleh peneliti terkait dengan speaking. Ini dilakukan sebagai upaya untuk memberikan solusi secara berkesinambungan terhadap masalahmasalah yang dihadapi oleh pelajar bahasa khususnya dalam speaking. Salah satu upaya yang telah diteliti yaitu pengajaran speaking dengan menggunakan video, seperti penelitian yang telah dilakukan oleh Ahlaro (2017), Hadi (2017), Ibda (2019), Roswita (2020), Ananda \& Mardiah (2020), Putra, Tastra, Suwatra (2014), dan Rozalinda (2021). Adapun tujuan dari penelitian mereka tersebut adalah untuk meningkatkan kemampuan speaking dan/atau mengidentifikasi pengaruh dari penggunaan video terhadap kemampuan speaking.

Pertama, penelitian yang telah dilakukan oleh Ahlaro (2017) yang 
berjudul Pengembangan Media Video Pembelajaran untuk Meningkatkan English Speaking Skill Bagi Pemelajar di Asrama Pendidikan Satu Atap Wasur Kabupaten Merauke. Hasil yang diperoleh atau temuan dari penelitian ini adalah mengembangkan media video pembelajaran yang diharapkan dapat membantu meningkatkan kecakapan berbahasa Inggris pemelajar di Asrama Pendidikan Satu Atap Wasur, Kabupaten Merauke. Model pengembangan yang digunakan dalam peneilitian ini yakni model Analisis, Design, Development, Implementation dan Evaluation (ADDIE). Untuk mengetahui kelayakan media video yang dikembangkan, maka dilakukan evaluasi terhadap aspek validitas, kepraktisan dan keefektifan media video dimaksud. Instrumen yang digunakan untuk mengumpulkan data terkait validitas dan kepraktisanmedia yakni, angket dan lembar observasi. Teknik yang digunakan untuk mengetahui keefektifan media video yang dikembangkan yakni one group pretest posttest design. Jumlah subyek yang dilibatkan dalam penelitian ini sebanyak 46 orang pemelajar (2 pemelajar sebagai subyek dalam one to one trial (uji coba perorangan), 8 pemelajar sebagai subyek dalam small group trial (uji coba kelompok kecil), 16 pemelajar sebagai subyek dalam field trial (uji coba kelompok besar) and 20 pemelajar sebagai subyek dalam pilot test). Hasil penelitian menunjukkan bahwa video yangdikembangkan telah dapat dikatakan valid, $96,7 \%$ rencana pembelajaran yang direncanakan telah dapat terlaksanakan sebagaimana direncanakan, oleh karena itu video tersebut dinilai praktis, dan signifikansi perbedaan nilai antara nilai pretest dan posttest adalah 0,00 (berada di bawah $0,05)$, oleh karenanya video tersbut telah dapat dikatakan efektif dalam meningkatkan English Speaking Skill para pemelajar.

Kedua, penelitian yang dilakukan oleh Hadi (2017) dengan judul Penerapan video pembelajaran untuk meningkatkan keterampilan berbicara dan menulis bahasa inggris. Adapun tujuan dari penelitiannya adalah untuk meningkatkan keterampilan berbicara dan menulis Bahasa Inggris kelas $X$ yang dilaksanakan di SMKN 10 Pandeglang, dengan jumlah peserta didik kelas $\mathrm{X}$ Akuntasi 126 peserta didik pada tahun pelajaran 2015-2016 dengan topik pembelajaran adalah The word is round dengan sub tema: teks deskriptif dan pengorganisasian struktur teks dan kalimat dalam teks. Metodologi penelitian yang dipergunakan dalam penelitian ini adalah penelitian tindakan (action research) karena penelitian dilakukan untuk memecahkan masalah pembelajaran di kelas. Penelitian ini menggunakan model Kemmis Mc. Taggart dalam bentuk spirat artinya dari siklus I ke siklus selanjutnya. Setiap siklus diliputi dengan rencana (planning), tindakan (action), pengamatan (observation), dan reflelsi (reflection). Berdasarkan temuan dan pembahasan yaitu penerapan media video film bahasa untuk meningkatkan keterampilan berbicara dan menulis peserta didik, yang ditandai dengan peningkatan ketuntasa belajar peserta didik dalam setiap siklus. Siklus I dalam keterampilan Berbicara (speaking) 92,31\%, keterampilan Menulis (writing) 80,77\%. Siklus II keterampilan Berbicara (speaking) 96,15\%, keterampilan Menulis (writing) 92, 31\%. Dan siklus III keterampilan Berbicara (speaking) 96,15\%, keterampilan Menulis (writing) $100 \%$ tuntas dalam pembelajaran menulis pada siklus III. 
Dalam peneram video pembelajaran mendapatkan respon atau pengaruh positif ditunjukan dengan nilai ratarata peserta didik bahwa peserta didik tertarik dan menerima penerapan video film dalam pembelajaran sehingga peserta didik termotivasi. Kesimpulan penelitian ini adalah 1) Penggunaan media video film bahasa meningkatkan aktivitas belajar peserta didik kelas X SMKN 10 Pandeglang, 2) Dengan menerapkan media video film pada keterampilan berbicara dan menulis Bahasa Inggris peserta didik kelas X SMKN 10 Pandeglang, 3) Perubahan keterampilan berbicara dan menulis Bahasa Inggris dalam menerapkan media video film pada peserta didik kelas $X$ SMKN 10 Pandeglang, 4) Terdapat peningkatan keterampilan berbicara dan menulis peserta didik dengan menerapkan media video film pada pembelajaran Bahasa Inggris kelas X SMKN 10 Pandeglang.

Ketiga, Penelitian yang telah dilakukan oleh Ibda (2019) Dengan Judul Peningkatan Keterampilan Berbicara Pada Mahasiswa Melalui Program Sama Savi (Satu Mahasiswa Satu Video). Penelitian ini bertujuan untuk meningkatkan keterampilan berbicara mahasiswa Program Studi Pendidikan Islam (PAI) STAINU Temanggung melalui Program"Satu Mahasiswa, Satu Video" (SAMA SAVI). Metode yang digunakan dalam penelitian ini adalah Penelitian Tindakan (PTK) dengan model Kurt Lewin. Sumber data penelitian ini berupa video karya 42 mahasiswa Prodi PAI STAINU Temanggung yang diunggah di Youtube. Hasil penelitian menunjukkan bahwa Program "Satu Mahasiswa, Satu Video" (SAMA SAVI) terbukti meningkatkan keterampilan berbicara mahasiswa Program Studi Pendidikan Islam (PAI) STAINU Temanggung.
Sebelum tindakan, keterampilan berbicara pada aspek kebahasaan dan aspek non-kebahasaan mahasiswa tidak memadai. Setelah tindakan siklus I dan siklus II, ada peningkatan yang signifikan dalam keterampilan berbicara mahasiswa, baik dari aspek kebahasaan dan nonkebahasaan. Dalam proses implementasi program ini, peneliti mengalami tujuh hambatan serta tujuh peluang untuk meningkatkan keterampilan berbicara mahasiswa.

Keempat, penelitian yang telah dilakukan oleh Roswita (2020) dengan judul Penggunaan media Video dalam Speaking. Adapun tujuan penelitian yang telah dilakukannya yaitu menganalisis penggunaan video dalam pengajaran speaking dengan menggunakan metode deskriptif kualitatif. Dari hasil angket yang telah dianalisanya ditemukan bahwa penggunaan video pada matakuliah speaking terbukti efektif, menarik, member manfaat kepada mahasiswa serta menunjang proses pembelajaran di kelas speaking pada program studi pendidikan bahasa Inggris FKIP Universitas Khairun.

Kelima, penelitian yang telah dilakukan oleh Ananda \& Mardiah (2020) dengan judul Pemanfaatan Video Blog (Vlog) Sebagai Media Pembelajaran Speaking Pada Siswa Sma Kelas Xi Di Yayasan Pendidikan Nur Hasanah Medan. Penelitian ini bertujuan untuk mendeskripsikan pemanfaatan Vlog sebagai media pembelajaran Speaking dan mendeskripsikan persepsi siswa pada penggunaan Vlog sebagai media pembelajaran. Metode penelitian yang digunakan dalam penelitian ini adalah metode campuran (mix method reserach) yang menghasilkan data berupa hasil persentase dari skala likert dan deskriptif berupa kata-kata tertulis atau lisan dari subjek penelitian. 
Subjek penelitian ini adalah siswa SMA kelas XI di Yayasan Pendidikan Nur Hasanah Medan yang berjumlah 24 siswa. Data penelitian ini dianalisis menggunakan tiga tahapan yaitu reduksi data, penyajian data dan penarikan kesimpulan. Berdasarkan hasil analisis data, diperoleh temuan sebagai hasil yang dicapai dalam penelitian ini yakni gambaran pemanfaatan vlog sebagai media dalam pembelajaran speaking dan persepsi siswa dalam pemanfaatan vlog sebagai media pembelajaran speaking dalam bahasa Inggris memberikan persepsi yang baik bagi siswa. Pengintegrasian dalam pemanfaatan vlog di kelas bahasa Inggris berhasil mewujudkan pembelajaran menjadi lebih menarik, meningkatkan persepsi baik siswa dalam menambah minat, dan juga ketertarikan siswa dalam pembelajaran speaking, sehingga siswa menganggap speaking tidak lagi hal yang sulit dan membosankan untuk dipelajari.

Keenam, penelitian yang telah dilakukan oleh Rozalinda (2021) yang berjudul Peningkatan Kemampuan Speaking English Melalui Metode Alm (Audio Lingual Method) Dengan Pemanfaatan Video Berbahasa Inggris Pada Siswa Kelas IX.1 MTsN 4 Kota Padang. Adapun tujuan penelitian ini adalah untuk mendeskripsikan proses kemampuan speaking English melalui metode ALM (Audio Lingual Method) dengan pemanfaatan video berbahasa inggris pada siswa kelas IX.1 MTsN 4 Kota Padang dan mendeskripsikan perubahan perilaku siswa kelas IX.1 MTsN 4 Kota Padang selama menggunakan metode ALM (Audio Lingual Method) dengan pemanfaatan video berbahasa inggris. Metode penelitian yang digunakan yaitu Penelitian Tindakan Kelas (PTK) yang terdiri atas dua siklus yaitu siklus I dan siklus II. Siklus I terdiri atas perencanaan, tindakan, observasi, dan refleksi. Siklus II juga terdiri atas perencanaan, tindakan, observasi, dan refleksi. Hasil penelitian menunjukkan adanya peningkatan proses kemampuan speaking English, menunjukkan adanya perubahan perilaku pada siswa, serta adanya peningkatan kemampuan speaking English. Siklus I nilai rata-rata kelas sebesar 67,3 dan siklus II sebesar 78 . Hal ini menunjukkan peningkatan dari siklus I hingga siklus II sebesar 10,67.

Ketujuh, Putra, Tastra, Suwatra. (2014). Dalam penelitiannya yang berjudul Pengembangan Media Video Pembelajaran dengan Model ADDIE pada Pembelajaran bahasa Inggris di SDN 1 Selat mereka menemukan bahwa video memiliki validitas yang baik dan layak untuk digunakan dalam proses pengembangan bahasa Inggris di SDN 1 Selat.

Kedelapan, penelitian yang telah dilakukan oleh Hendrayani (2020) yang berjudul Penggunaan Video untuk Meningkatkan Keterampilan Berbicara Siswa pada Mata Pelajaran bahasa Inggris

Materi offering services di Kelas XII Jasa Boga 4 Semester 1 SMK Negeri 3 Bogor tahun pelajaran 2017/2018, dari hasil penelitiannya ditemukan bahwa penggunaan video dalam pembelajaran bahasa Inggris untuk materi offering services dapat mendorong siswa untuk lebih aktif di kelas dan membantu mereka meraih nilai yang lebih baik dan memenuhi standar acuan KKM. Untuk itu, peneliti mendorong penggunaan video ini untuk dapat disosialisasikan sebagai metode alternative dalam pembelajaran Bahasa Inggris di lingkungan Dinas Pendidikan Provinsi Jawa Barat, khususnya di area Bogor dan sekitarnya.

Selanjutnya, Supiningsih (2019) dalam penelitiannya yang berjudul 
Efektifitas Media Pembelajaran Video Scribe Dalam Bahasa Inggris Pada Simple Present Tense di temukan bahwa penerapan media video scribe dapat meningkatkan prestasi belajar siswa kelas X TKR 2, ditunjukkan dengan peningkatan nilai rata-rata kelas dari kondisi awal 74,70 menjadi 78,1 serta peningkatan ketuntasan belajar dari kondisi awal 20 meningkat menjadi 27.

Terakhir, penelitian yang telah dilakukan oleh Wijayanti \& Gunawan (2021) yang berjudul Pengajaran bahasa Inggris dengan bantuan media video pendek youtube. Hasil Evaluasi menunjukkan bahwa sebagian besar siswa memperoleh nilai baik, sehingga terbukti bahwa belajar kosakata menggunakan video pendek YouTube bermanfaat bagi siswa selama instruksinya disiapkan dengan baik.

Dari beberapa penelitian terkait penggunaan video dalam pengajaran speaking terbaru di atas dapat disimpulkan bahwa video memiliki kelebihan dan keunggulan dari pada media lainnya pada saat digunakan dalam pengajaran speaking. Sehingga dapat dilihat dari hasil penelitian tersebut bahwa video mampu meningkatkan motifasi, semangat, daya tarik, dan nilai speaking mahasiswa/siswa. Video yang telah digunakan dalam penelitian tersebut telah dikombinasikan dengan media lain atau memiliki sumber yang berbeda, seperti video yang diambil dari you tube, video blog, dan ada juga penggabungan video dengan audio lingual method. Dari sekian jenis video yang telah digunakan, peneliti belum memenukan adanya penggunaan media BIP Video Call, oleh karena itu peneliti sangat tertarik untuk meneliti tentang penggunaan media BIP Video Call dalam pengajaran Speaking for everyday Communication pada mahasiswa semester II program studi pendidikan bahasa Inggris FKIP UNILAK.

\section{METODE}

Untuk mengumpulkan data tentang penggunaan media BIP Video Call dalam pengajaran speaking pada mahasiswa semester II program studi pendidikan bahasa Inggris FKIP Unilak, sebagai evaluasi diakhir pertemuan, peneliti telah memberikan tes speaking. Jenis tesnya adalah descriptive speaking secara individu. Masing-masing mahasiswa mendeskripsikan salah satu topik pada mata kuliah speaking for everyday communication paling lama lima menit dengan menggunakan media BIP Video Call. Untuk menentukan penilaian test speaking, peneliti menggunakan rubrik yang telah di tentukan oleh Hughes (1990) sebagai berikut beserta kriteria penilaiannya:

\section{Accent (Pengucapan)}

1. Pronunciation frequently unintelligible

2. Frequent gross and a very heavy accent make understanding difficult, require frequent repetition

3. "Foreign Accent" requires concentrated listening, mispronunciation lead to occasional misunderstanding and apparent errors in grammar or vocabulary

4. Marked "Foreign Accent" and occasional mispronunciation which do not interfere with understanding

5. No conspicuous mispronunciation, but would not be taken for a native speaker

6. Native pronunciation, with no trace of "foreign accent"

\section{Grammar (Tata Bahasa)}

1. Grammar almost entirely in accurate phases 
2. Constant error showing control of very few major patterns and frequently preventing communication.

3. Frequent errors showing some major patterns uncontrolled and causing occasional irritation and misunderstanding

4. Occasional errors showing imperfect control of some patterns but no weakness that causes misunderstanding

5. Few errors, with no patterns of failure

6. No more than two errors during the speech

\section{Vocabulary (Kosakata)}

1. Vocabulary inadequate for even the simplest conversation

2. Vocabulary limited to basic personal and survival areas

3. Choice of words sometimes inaccurate, limitations of vocabulary prevent discussion of some common professional and social topic

4. Professional vocabulary adequate to discuss special interest; general vocabulary permits discussion of any non-technical subject with some circumlocutions

5. Professional vocabulary broad and precise; general vocabulary adequate to cope with complex and practical problems and varied social situations

6. Vocabulary apparently as accurate and extensive as that of an educated native speaker

\section{Fluency (Kelancaran)}

1. Speech is so halting and fragmentary that conversation is virtually impossible

2. Speech is very slow and uneven except for short or routine sentences 3. Speech is frequently hesitant and jerky; sentences may be left uncompleted
4. Speech is occasionally hesitant, with some unevenness caused by rephrasing and groping for words

5. Speech is effortless and smooth, but perceptibly non-native in speech and evenness

6. Speech or all professional and general topics as effortless and smooth as a native speaker's

\section{Comprehension (Pemahaman)}

1. Understands too little for the simples type of conversation

2. Understands only slow, very simple speech on common social and tourist topics;

requires constant repetition and rephrasing.

3. Understands careful, somewhat simplified speech when engaged in a dialogue, but may require considerable repetition and rephrasing

4. Understands quite well normal educated speech when engaged in a dialogue, but requires occasional repetition or rephrasing

5. Understands everything in normal educated conversation except for very colloquial or low frequency items, or exceptionally rapid or slurred

Tujuan penelitian ini adalah untuk mendeskripsikan kemampuan speaking mahasiswa Pendidikan bahasa Inggris Fakultas Keguruan dan Ilmu Pendidikan (FKIP) universitas Lancang Kuning (UNILAK) Pekanbaru, mahasiswa Tahun Akademik 2020/2021. Hasil penelitian ini nantinya diharapkan dapat memberikan kontribusi terhadap ilmu pengetahuan. Dintaranya adalah dengan diterbitkannya artikel ilmiah yang akan dipublikasikan di jurnal ilmiah, sehingga nantinya dapat menjadi bahan rujukan bagi peneliti/pembaca yang membutuhkan teori atau hasil penelitian yang relevan dengan penelitian ini khususnya dalam 
pengajaran Speaking dengan menggunkan BIP Video Call.

\section{HASIL DAN PEMBAHASAN}

Penelitian ini telah dilakukan selama 7 (tujuh) bulan, mulai dari bulan Februari hingga September tahun 2021. Tempat penelitian adalah program studi pendidikan bahasa Inggris FKIP Unilak Pekanbaru. Pada penelitian ini tidak digunakan istilah populasi dan sample, tapi memakai istilah participant. Yang menjadi participant pada penelitian ini adalah mahasiswa semester II pendidikan bahasa Inggris Tahun Akademik 20202021 berjumlah 23 orang. Pendekatan yang digunakan dalam penelitian yaitu mix model, penggabungan data kuantitatif dan data kualitatif dalam bentuk Penelitian Tindakan Kelas. Data kuantitatif diperoleh dari hasil tes speaking sedangkan data kualitatif diperoleh dari wawancara. Penelitian ini merupakan penelitian tindakan kelas yang terdiri dari beberapa pertemuan dan siklus. Pada penelitian ini direncanakan sebanyak 3 pertemuan dalam 1 siklus. Siklus tersebut terdiri dari beberapa komponen, seperti Planning, Action, Observation, dan Reflection.

Penelitian ini dilakukan dengan tiga tahap, yaitu tahap persiapan, pelaksanaan, dan analisis data.

\section{Tahap Persiapan}

a) Melakukan observasi kajian pustaka yang sesuai dengan rumusan masalah yang akan diteliti, dan melakukan orientasi lapangan serta koordinasi antara peneliti dengan ketua program studi pendidikan bahasa Inggris FKIP Unilak.

b) Menyusun perangkat instrumen. Tes ini berbentuk tes speaking di mana mahasiswa diminta untuk mendeskripsikan salah satu topic pada mata kuliah speaking for everyday communication dengan menggunakan media BIP Video Call. Masing-masing akan mendeskripsikan topik tersebut selama lima menit maksimal.

c) Penetapan participant penelitian. Mahasiswa semester II program studi pendidikan bahasa Inggris FKIP UNILAK tahun akademik 2020-2021 terdiri dari tiga kelas; 2.1, 2.2, dan 2.3. Yang menjadi partisipan pada penelitian ini satu kelas saja yaitu kelas 2.1. Kelas ini dijadikan participant karena mereka memiliki kemampuan speaking yang lebih rendah dari kelas yang lain.

\section{Tahap Pelaksanaan Penelitian}

Tahap ini merupakan tahap pengumpulan data. Langkah-langkah yang dilakukan adalah sebagai berikut:

\section{a. Planning}

Tahapan ini merupakan langkah awal sebelum dilakukan penelitian atau proses perkuliahaan. Adapun kegiatan yang dilakukan yaitu:

a) Menyusun RPS matakuliah Speaking for Everyday Communication

b) Menyiapkan media BIP Video Call

b. Action

Tahapan ini merupakan proses mengaplikasikan media BIP Video call dalam pengejaran Speaking for Everyday Communication. Adapun kegiatan yang dilakukan sebagai berikut:

a) Greeting atau salam

b) Warming Up atau pemanasan

c) Mengabsensi

d) Menentukan topic yang akan disampaikan

e) Mengajarkan mahasiswa topik Speaking for Everyday Communication dengan menggunakan media BIP Video Call.

c. Observation

Pada tahapan ini, peneliti mengamati proses pembelajaran speaking dengan menggunakan media BIP video call 
sambil mencatat hal-hal yang terjadi atau yang tampak melalui video tersebut.

\section{d. Reflection}

Tahapan ini merupakan tahapan untuk mengevaluasi kegiatan sebelumnya. Peneliti akan mengevaluasi hasil tes speaking mahasiswa dan menganalisa faktorfaktor yang memengaruhi dari hasil pengamatan dan catatan lapangan yang telah diambil selama proses perkuliahan. Jika nilai speaking mahasiswa rendah atau belum mencapai target meinimum, maka akan dilanjutkan dengan siklus yang kedua.

\section{Pengolahan dan Analisis Data}

Setelah data dikumpulkan melalui instrumen penelitian yang sudah dijelaskan di atas, peneliti akan menganalisi data hasil tes speaking dengan menggunakan rubrik yang telah ditentukan di atas. Selanjutnya, nilai tersebut dikonversi kedalam kategori yang telah dirumuskan oleh Leo (2006).

Merujuk kepada hasil penelitian di atas diketahui bahwa kemampuan speaking mahasiswa Pendidikan bahasa Inggris FKIP-UNILAK Tahun Akademik 2020/2021 semester 2.1 berada pada level poor dengan nilai rata-rata 53,3. Tidak ada perbedaan antara penggunaan media Video WhatsApp, atau Video lainnya dengan kemampuan speaking mereka ketika menggunakan media BIP Video Call.

Hasil penelitian ini memiliki sedikit kesamaan dengan penelitian terdahulu yang dilakukan oleh Hadi (2017) dengan judul Penerapan video pembelajaran untuk meningkatkan keterampilan berbicara dan menulis bahasa inggris. Kesimpulan penelitian ini adalah 1) Penggunaan media video film bahasa meningkatkan aktivitas belajar peserta didik kelas $\mathrm{X}$
SMKN 10 Pandeglang, 2) Dengan menerapkan media video film pada keterampilan berbicara dan menulis Bahasa Inggris peserta didik kelas $\mathrm{X}$ SMKN 10 Pandeglang, 3) Perubahan keterampilan berbicara dan menulis Bahasa Inggris dalam menerapkan media video film pada peserta didik kelas X SMKN 10 Pandeglang, 4) Terdapat peningkatan keterampilan berbicara dan menulis peserta didik dengan menerapkan media video film pada pembelajaran Bahasa Inggris kelas $\mathrm{X}$ SMKN 10 Pandeglang.

Kedua, Penelitian yang telah dilakukan oleh Ibda (2019) Dengan Judul Peningkatan Keterampilan Berbicara Pada Mahasiswa Melalui Program Sama Savi (Satu Mahasiswa Satu Video). Penelitian ini bertujuan untuk meningkatkan keterampilan berbicara mahasiswa Program Studi Pendidikan Agama Islam (PAI) STAINU Temanggung melalui Program"Satu Mahasiswa, Satu Video" (SAMA SAVI). Metode yang digunakan dalam penelitian ini adalah Penelitian Tindakan (PTK) dengan model Kurt Lewin. Sumber data penelitian ini berupa video karya 42 mahasiswa Prodi PAI STAINU Temanggung yang diunggah di Youtube. Hasil penelitian menunjukkan bahwa Program "Satu Mahasiswa, Satu Video" (SAMA SAVI) terbukti meningkatkan keterampilan berbicara mahasiswa Program Studi Pendidikan Islam (PAI) STAINU Temanggung. Sebelum tindakan, keterampilan berbicara pada aspek kebahasaan dan aspek non-kebahasaan mahasiswa tidak memadai. Setelah tindakan siklus I dan siklus II, ada peningkatan yang signifikan dalam keterampilan berbicara mahasiswa, baik dari aspek kebahasaan dan nonkebahasaan. Dalam proses implementasi program ini, peneliti mengalami tujuh hambatan 
serta tujuh peluang untuk meningkatkan keterampilan berbicara mahasiswa.

Ketiga, penelitian oleh Surani \& Chaerudin (2019) dengan judul Pemanfaatan Media WhatsApp Grouping dalam Peningkatan Kemampuan Bahasa Inggris Ekonomi Mahasiswa Fakultas Ekonomi dan Bisnis, ditemukan bawha Keberadaan Grup WhatsApp berguna untuk mendukung kuliah Ekonomi Inggris 1, media informasi yang akurat tentang perkuliahan untuk pengiriman materi dan tugas, pengumpulan tugas, baik dalam bentuk komentar langsung dalam obrolan, gambar / keterangan, rekaman dialog cepat. Group WhatsApp juga terbukti bermanfaat dalam meningkatkan keterampilan Bahasa Inggris Ekonomi termasuk kemampuan mendengarkan, menulis, membaca dan berbicara.

Selanjutnya, penelitian yang dilakukan oleh Sulistio (2021) yang berjudul Peningkatan Prestasi Belajar bahasa Inggris Melalui Pembelajaran Jarak Jauh (PJJ) dalam Penerapan Pembelajaran Sinkron dan Asinkron melalui Google Classroom, Google meet

dan Aplikasi e-learning, ditemukannya bahwa penerapan asinkron dengan menggunakan e-learning, grup WA dan sinkron dengan menggunakan google meet dan video conference mampu meningkatkan prestasi belajar bahasa Inggris siswa/i kelas XII MAN 4 Kediri.

Terakhir, penelitian yang telah dilakukan oleh Nurlaili \& Hasibuan (2021) dengan judul Penerapan Computer Assisted Language Learning (CALLl) dengan bantuan menggunakan media video dalam meningkatkan speaking ability. Penelitian yang telah mereka melakukan dengan menggunakan metode Penelitian Tindakan Kelas (PTK) dimana melakukan dua siklus. Masing- masing siklus terdiri dari empat langkah. Adapun keempat langkah tersebut adalah, perencanaan, pelaksanaan, observasi, dan refleksi.

Subjek penelitian ini adalah mahasiswa semester VII kelas O FKIP Program Pendidikan Bahasa Inggris yang berjumlah 14 orang. Data dianalisis secara deskriptif dan hasil penelitian ini menunjukkan bahwa dengan proses pembelajaran penerapan Computer Assisted Language Learning (CALL) dengan bantuan menggunakan video sangat bagus untuk proses pembelajaran dimana mahasiswa menjadi aktif dan termotivasi dan bahkan menyenangkan dalam mempraktekkan kemampuan bahasa inggris mereka pada bidang English for job hunting (pencarian pekerjaan). Dan juga nilai dari Speaking ability (kemampuan berbicara) mahasiswa pada bidang English for job hunting ini mengalami peningkatan. Dimana yang nilai awal sebelum ada tindakan hanya $68 \%$, kemudian dilakukan tindakan pada siklus I meningkat menjadi 75 . $35 \%$, setelah tindakan pada siklus I

dilakukan maka lanjut pada tindakan pada siklus II meningkat menjadi $80.71 \%$. Dengan ketuntasan nilai tersebut bahwa tanggapan mahasiswa pada penerapan metode CALL dengan bantuan menggunakan video ini dikatakan positif.

Dibandingkan dengan beberapa penelitian di atas, ada sedikit kesamaan dengan penelitian yang telah peneliti lakukan. Kesamaannya bahwa Video bisa membantu siswa/i atau mahasiswa dalam meningkatkan kemapuan berbicara mereka. Namun, terdapat juga beberapa perbedaan dengan beberapa penelitian tersebut di atas. Pertama, jenis video yang digunakan berbeda antara satu denga yang lainnya. Hadi (2017) pada penelitiannya telah menggunakan video film, Ibda (2019) dalam penelitiannya 
telah menggunakan SAMA SAVI (Satu Mahasiswa Satu Video), Sulistio (2021) yang berjudul Peningkatan Prestasi Belajar bahasa Inggris Melalui Pembelajaran Jarak Jauh (PJJ) dalam Penerapan Pembelajaran Sinkron dan Asinkron melalui Google Classroom, Google meet dan Aplikasi e-learning, ditemukannya bahwa Penerapan asinkron dengan menggunakan elearning, grup WA dan sinkron dengan menggunakan google meet dan video conference, dan Nurlaili dan Hasibuan (2021) dengan judul Penerapan Computer Assisted Language Learning (CALLl) dengan bantuan menggunakan media video, sementara penelitian yang telah peneliti lakukan menggunakan BIP Video Call.

\section{KESIMPULAN}

Berdasarkan nilai quiz dan test mahasiswa Pendidikan bahasa Inggris semester II FKIP UNILAK yang telah diperoleh, dapat dilihat bahwa perubahan nilainya tidak begitu signifikan, namun sudah ada perubahan. Berdasarkan hasil wawancara via WhatsApp dengan beberapa perwakilan dari partisipan, mereka mengatakan bahwa ada beberapa faktor yang menyebabkan adanya sedikit perubahan pada kemampuan berbicara mereka dengan menggunakan media BIP Video Call. Pertama, Video Call dengan BIP menghasilkan bunyi atau suara yang jelas, sehingga mereka mudah mencerna apa yang sedang disampaikan lawan bicaranya pada saat itu, dan mereka pun mudah untuk meresponnya. Kedua, Visualisasi Video BIP juga lebih jelas dibandingkan dengan whatsApp. Kejelasan pada visualisasi tersebut membantu mereka untuk memahami apa yang sedang diucapkan oleh lawan bicara mereka, dengan demikian mereka juga terbantu untuk merespon apa yang sedang dibicarakannya. Jadi, BIP Video Call memiliki dua keunggulan dari media yang lainnya teutama WhatsApp yaitu menghasilkan bunyi dan visualisasi yang lebih jelas.

\section{DAFTAR PUSTAKA}

Ahlaro, S. R. (2017). Pengembangan Media Video Pembelajaran Untuk Meningkatkan English Speaking Skill Bagi Pemelajar di Asrama Pendidikan Satu Atap Wasur Kabupaten Merauke. Jurnal Masalah Pastoral, 5(1), 19. Retrieved from https://ojs.stkyakobus.ac.id/inde x.php/JUMPA/article/view/35.

Al-Jarf, R. (2012). Chapter Six Mobile Technology and Student Autonomy in Oral Skill Acquisition. Left to My Own Devices: Learner Autonomy and Mobile- Assisted Language Learning, 6, p.105.

Ananda \& Mardiah. (2020). Pemanfaatan video blog (vlog) sebagai media pembelajaran speaking pada siswa sma kelas xi di yayasan pendidikan nur hasanah medan. Jurnal Visipena Volume 11, Nomor 2, Desember $2020 \quad P$-ISSN 2086-1397 EISSN 2502-6860.

Hadi, D.S. (2017). The Application of Leaning Video to Improve English Speaking and Writing Skill SMK Negeri 10 Pandeglang. Jurnal Teknologi Pendidikan dan Pembelajaran Tahun 4, Nomor 2 November 2017: Teknologi Pembelajaran Pascasarjana Universitas Sultan Ageng Tirtayasa.

Hakim, M.A.R. (2015). Experienced EFL teachers' challenges and strategies in teaching speaking for introvert students. European 
Journal of Social Sciences, 48(4), pp.437-446.

Hendrayani. (2020). Penggunaan Video untuk Meningkatkan Keterampilan Berbicara Siswa pada Mata Pelajaran bahasa Inggris Materi offering services di Kelas XII Jasa Boga 4 Semester 1 SMK Negeri 3 Bogor tahun pelajaran 2017/2018. Jurnal Pendidikan BINANIAGA Vol. 01, No. 01, Januari 2020.

Hughes. (1990). Testing for Language Teacher $\left(2^{\text {nd }} e d\right)$. United Kingdom: Cambridge.

Ibda. (2019). Peningkatan keterampilan berbicara pada mahasiswa melalui program sama savi (satu mahasiswa satu video). Jurnal pena Indonesia, Jurnal Bahasa Indonesia, Sastra, dan Pengajarannya Volume 5, Nomor 1, Maret 2019 ISSN: 22477-5150, e-ISSN: 25492195.

Leo, S. (2006). English for Leisure Time Speaking. Jakarta: Gramedia Pustaka Utama.

Nurlaili \& Hasibuan. (2021). Penerapan Computer Assisted Language Learning (CALLl) dengan bantuan menggunakan media video dalam meningkatkan speaking ability. Jurnal Penelitian Pendidikan Bahasa dan Sastra Vol. 6 No. 2. Oktober 2021.

Putra, Tastra, Suwatra. (2014). Pengembangan Media Video Pembelajaran dengan Model ADDIE pada Pembelajaran bahasa Inggris di SDN 1 Selat.
e-Jurnal Edutech Universitas Pendidikan Ganesha Jurusan Teknologi Pendidikan (vol: 2 No: 1 Tahun: 2014)

Roswita. (2020). Penggunaan Media Video dalam Pembelajaran Speaking. Jurnal Penelitian Humano Vol 11 No 1 Edisi Juni 2020. ISSN 19786115.

Supiningsih. (2019). Efektifitas Media Pembelajaran Video Scribe Dalam Bahasa Inggris Pada Simple Present Tense. Wacana Akademika: Majalah Ilmiah Kependidikan Volume 3 No 1 Tahun 2019.

Surani \& Chaerudin, A.R. (2019). Pemanfaatan Media Whatsapp Grouping dalam Peningkatan Kemampuan Bahasa Inggris Ekonomi Mahasiswa Fakultas Ekonomi dan Bisnis. http://jurnal.uinbanten.ac.id/ind ex.php/tarbawi/article/view/205 $0 / 1880$.

Sulistio. (2021). Peningkatan Prestasi Belajar bahasa Inggris Melalui Pembelajaran Jarak Jauh (PJJ) dalam Penerapan Pembelajaran Sinkron dan Asinkron melalui Google Classroom, Google meet dan Aplikasi e-learning. SECONDARY : Jurnal Inovasi Pendidikan Kejuruan Vol. 1 No. 2 Tahun 2021

Wijayanti \& Gunawan. (2021). Pengajaran bahasa Inggris dengan bantuan media video pendek youtube. RESONA Jurnal IImiah Pengabdian Masyarakat. https://journal.stiem.ac.id/index. php/resona/article/view/637/454 